\title{
Development of iron-rich whey protein hydrogels following application of ohmic heating - Effects of moderate electric fields
}

\author{
Ricardo N. Pereira ${ }^{\mathrm{a}, *}$, Rui M. Rodrigues ${ }^{\mathrm{a}}$, Emir Altinok ${ }^{\mathrm{b}}$, Óscar L. Ramos ${ }^{\mathrm{a}, \mathrm{c}}, \mathrm{F}$. Xavier Malcata $^{\mathrm{c}, \mathrm{d}}$, \\ Paola Maresca ${ }^{\mathrm{e}}$, Giovanna Ferrari ${ }^{\mathrm{b}, \mathrm{e}}$, José A. Teixeira ${ }^{\mathrm{a}}$, António A. Vicente ${ }^{\mathrm{a}}$ \\ ${ }^{\text {a }}$ CEB - Centre of Biological Engineering, University of Minho, 4710-057 Braga, Portugal \\ b Department of Industrial Engineering, University of Salerno, via Giovanni Paolo II, 132, Fisciano, SA, Italy \\ c LEPABE - Laboratory for Process Engineering, Environment, Biotechnology and Energy, University of Porto, Porto, Portugal \\ d Department of Chemical Engineering, University of Porto, Porto, Portugal \\ e ProdAl Scarl - University of Salerno, via Ponte don Melillo, 84084 Fisciano, (SA), Italy
}

A R T I C L E I N F O

\section{Keywords:}

Whey protein isolate

Electric fields

Iron

Cold gelation

Transmission electron microscopy

\begin{abstract}
A B S T R A C T
The influence that ohmic heating technology and its associated moderate electric fields (MEF) have upon production of whey protein isolate cold-set gels mediated by iron addition was investigated. Results have shown that combining heating treatments $\left(90^{\circ} \mathrm{C}, 5 \mathrm{~min}\right.$ ) with different MEF intensities let hydrogels with distinctive micro and macro properties - i.e. particle size distribution, physical stability, rheological behavior and microstructure. Resulting hydrogels were characterized (at nano-scale) by an intensity-weighted mean particle diameter of $145 \mathrm{~nm}$, a volume mean of $240 \mathrm{~nm}$. Optimal conditions for production of stable whey protein gels were attained when ohmic heating treatment at a MEF of $3 \mathrm{~V} \cdot \mathrm{cm}^{-1}$ was combined with a cold gelation step using $33 \mathrm{mmol} \cdot \mathrm{L}^{-1}$ of $\mathrm{Fe}^{2+}$. The consistency index of hydrogels correlated negatively to MEF intensity, but a shear thickening behavior was observed when MEF intensity was increased up to $10 \mathrm{~V} \cdot \mathrm{cm}^{-1}$. According to transmission electron microscopy, ohmic heating gave rise to a more homogenous and compact fine-stranded whey protein-iron microstructure. Ohmic heating appears to be a promising technique, suitable to tailor properties of whey protein gels and with potential for development of innovative functional foods.
\end{abstract}

\section{Introduction}

Proteins are important food ingredients due to a unique combination of biological nutritional and functional properties. They provide essential amino acids, and exhibit a range of dynamic and functional properties, with a particularly high versatility for processing. They can be used to form networks, structures and to interact with other components, thus improving quality attributes in foods (Yada, Jackman, \& Smith, 1994). Whey proteins, such as $\beta$-lactoglobulin ( $\beta$-lg) that constitutes more than $50 \%$ of the total protein in whey, followed by $\alpha$-lactalbumin ( $\alpha$ lac) and bovine serum albumin (BSA) that represent $20 \%$ and $5 \%$, respectively, are good examples of functional proteins (Nicorescu et al., 2008). Their ability to interact and form aggregates determines the functional and technological properties of products derived therefrom, such as whey protein isolate (WPI) and whey protein concentrate (WPC). Due to their particular structures and physicochemical properties, $\beta-1 g$ and whey protein aggregates have been extensively employed in applications, namely for gel formation, emulsions and foams stabilization, films and coatings, and encapsulation of labile and/or active compounds (Nicolai, Britten, \& Schmitt, 2011).

The functionality of a protein is closely related to its structure and is usually triggered by an initial step of unfolding that causes disruption of its secondary and tertiary structures, thus altering the surface exposure of amino acids. This phenomenon eventually produces an increased interaction potential (Foegeding \& Davis, 2011), and lead to formation of small oligomers that may further interact to form aggregates, and ultimately a continuous network called gel (Totosaus, Montejano, Salazar, \& Guerrero, 2002). Extent and rate of aggregation are strongly dependent of environmental conditions such as protein concentration, temperature, $\mathrm{pH}$, ionic strength and ion type (Bryant \& McClements, 1998).

Cold gelation is a two-step process: unfolding of the protein is first promoted by heating the solution above the denaturation temperature; while the second step is carried out at room temperature, and consists either of changing $\mathrm{pH}$ or adding of salts. In salt-induced gelation of globular whey proteins or whey protein isolate, salts such as $\mathrm{NaCl}$ and $\mathrm{CaCl}_{2}$ are commonly used. Slow addition of these salts to a heat

\footnotetext{
* Corresponding author.

E-mail address: rpereira@deb.uminho.pt (R.N. Pereira).
} 
denaturated whey protein solution help to screen the electrostatic repulsion or form salt bridges between negatively charged on proteins and molecules and aggregates, thus facilitating gelation (Ako, Nicolai, \& Durand, 2010; Marangoni, Barbut, McGauley, Marcone, \& Narine, 2000; Martin \& Jong, 2012); gels produced by this method have shown higher strength and water-holding capacity than gels formed by heat-induced gelation (Bryant \& McClements, 2000; Nicolai et al., 2011). Iron has also been reported to induce aggregation and gel formation in pre-heated protein solutions (Remondetto, Paquin, \& Subirade, 2002; Remondetto \& Subirade, 2003). Furthermore, it provides nutritional value - and there is evidences that iron entrapment or binding in whey protein structures prevents its oxidation, enables controlled release and increases bioavailability (Martin \& de Jong, 2012a; Nakano, Goto, Nakaji, \& Aoki, 2007; Remondetto, Beyssac, \& Subirade, 2004).

Ohmic heating, also known for its moderate electric fields (MEF), is an emergent technology in food processing that is gaining interest in industrial applications. However, very few works have dealt with effects of MEF at structural level, particularly on proteins, and none of them has focused on its effects upon cold-gelation of proteins. It has been reported that MEF influence whey protein denaturation (Pereira, Teixeira, \& Vicente, 2011), affect aggregation and properties of protein networks (Lei, Zhi, Xiujin, Takasuke, \& Zaigui, 2007; Pereira, Souza, Cerqueira, Teixeira, \& Vicente, 2010). In this study, a combination of MEF treatments and cold-gelation with divalent iron $\left(\mathrm{Fe}^{2+}\right)$ was for the first time performed. Electrical and thermal effects of ohmic heating technology are expected to minimize protein denaturation, as well as to influence functional aspects of soluble proteins by changing size and morphology of the primary protein aggregates in a very distinctive way. These events and this structural hierarchy should not be overlooked once represent a great impact on gel-forming properties of a given protein matrix (Marangoni et al., 2000), thus offering the potential to create novel possibilities for development of protein microstructures at mild conditions (i.e. form scaffolds) and gels with unique functionality (e.g. enhancement of interaction or binding potential) nutritional content (i.e. high preservation of native protein with biological functions) that need to be ascertained. Therefore, the present study aimed at determining the combined influence of ohmic heating performed at different MEF intensities on cold gelation of whey protein solutions induced by $\mathrm{Fe}^{2+}$, via characterization of size, shape and mechanical features of the protein aggregates and gels formed. Low protein concentration, acid solution conditions and a moderate ionic strength were chosen in order to promote formation of small soluble aggregates during heat treatments (Dissanayake, Ramchandran, Piyadasa, \& Vasiljevic, 2013), thus allowing further aggregation and gelation of said structures following addition of $\mathrm{Fe}^{2+}$.

\section{Material and methods}

\subsection{Materials}

WPI powder (Lacprodan DI-9212) was kindly supplied by Arla Foods Ingredients (Viby, Denmark). With a $\beta$-lg content of ca. $87 \%$, in a total protein content of $91 \%$ (in dry weight) and trace contents of lactose (max. $0.5 \%)$ and fat (max. $0.2 \%$ ). Ultrapure water (with a resistivity of $18.2 \mathrm{M} \Omega \cdot \mathrm{cm}$ and electrical conductivity $0.06 \mu \mathrm{S} / \mathrm{cm}$ at $25{ }^{\circ} \mathrm{C}$ ) was used to prepare WPI dispersions, and was previously obtained with a Milli-Q Ultrapure water purification system (Millipore, Bedford MA, USA). Sodium chloride (ASC reagent grade) supplied by Sigma-Aldrich (Germany) was used to adjust electrical conductivity of WPI solutions. Iron (II) sulfate heptahydrate $\left(\mathrm{FeSO}_{4} \cdot 7 \mathrm{H}_{2} \mathrm{O}\right)$ from Sigma-Aldrich (Germany) was used to induce cold gelation of WPI. All other chemicals used were of analytical reagent (AR) grade.

\subsection{Whey protein solutions}

Aqueous solutions of WPI $(3 \%, w / v)$ were prepared in ultrapure water and $0.1 \mathrm{~mol} \cdot \mathrm{L}^{-1}$ of $\mathrm{NaCl}$ and $5 \mathrm{~mol} \cdot \mathrm{L}^{-1}$ of $\mathrm{HCl}$ (AR grade, Sigma-Aldrich, Germany) were used (as necessary) to adjust $\mathrm{pH}$ to 3.0. The WPI solution was then stirred for $2 \mathrm{~h}$ and let overnight at $5{ }^{\circ} \mathrm{C}$ to ensure full rehydration. Conditions chosen of WPI and $\mathrm{NaCl}$ concentration resulted in a conductivity of the solutions of ca. $12 \mathrm{mS} \cdot \mathrm{cm}^{1}$, which allowed the Joule effect to take place during ohmic heating.

\subsection{Heating method}

WPI solutions of $20 \mathrm{ml}$ were heated at $90{ }^{\circ} \mathrm{C}$ for a holding time of 5 min via different heating methods: 1 ) Ohmic heating at different MEF intensities; and 2) a conventional water-bath heating performed without presence of electric field (i.e. $0 \mathrm{~V} \cdot \mathrm{cm}^{-1}$ ). Protein solution conditions (e.g. in terms of protein concentration, $\mathrm{pH}$ and salt amount) and heating protocol allowed protein denaturation degrees above $90 \%$, independently of heating method applied (Pereira et al., 2011) After the holding phase, aliquots of heated samples $(1 \mathrm{~mL})$ were removed and cooled immediately in ice for $5 \mathrm{~min}$.

\subsubsection{Conventional heating}

Conventional heating as performed in a double-walled waterjacketed reactor vessel with $30 \mathrm{~mm}$ of internal diameter and $100 \mathrm{~mm}$ height, as reported in previous works (Pereira et al., 2010; Rodrigues et al., 2015). Temperature was raised and controlled by a circulating water-bath set at the holding temperature of the treatment to avoid temperature abuses. A type-K thermocouple $\left(1{ }^{\circ} \mathrm{C}\right.$, Omega, 709 , U.S.A. $)$ was placed at the geometric center of the sample volume and connected to a data logger (National Instruments, USB-9161, U.S.A.) thus allowing temperature be measured during processing. Samples were stirred during heating cycle using a magnetic stirrer (size of $0.5 \mathrm{~cm}$ ) at $150 \mathrm{rpm}$, thus improving heat transfer and allowing better sample homogenization of the solutions.

\subsubsection{MEF treatments}

MEF treatments were applied in a cylindrical glass reactor $(300 \mathrm{~mm}$ total length and $23 \mathrm{~mm}$ inner diameter), as described previously (Pereira et al., 2010; Pereira et al., 2011; Rodrigues et al., 2015). The supplied voltage, ranging from 0.3 to $170 \mathrm{~V}$, was controlled via a function generator (Agilent 33220A, Penang, Malaysia, $1 \mathrm{~Hz}-25 \mathrm{MHz}$ and 1 to $10 \mathrm{~V}$ ) connected to an amplifier (Peavey CS3000, Meridian, MS, USA). During the MEF treatments, temperature was controlled through adjustment of the supplied voltage. Electric field intensity $\left(\mathrm{E}_{\mathrm{F}}\right)$ varied from 0 to $10 \mathrm{~V} \cdot \mathrm{cm}^{-1}$, during heating holding phase. Temperature was measured during treatments as described in Section 2.3.1. To exclude shearing conditions, as a potential reason for different aggregation behavior of whey protein, sample volume and stirring conditions were identical, as described previously for conventional heating treatments. A close coincidence of temperature profiles during MEF treatments at distinct field strengths was a necessary condition to ascertain existence of non-thermal effects.

\subsection{Induced gelation at room temperature}

Cold gelation of whey proteins requires a heating treatment to denature and turn whey proteins into soluble aggregates, followed by a cooling step and addition of a ferrous salt. This procedure generates a network of whey protein aggregates mediated by $\mathrm{Fe}^{2+}$ ions (Remondetto et al., 2002; Remondetto et al., 2004). In this study, cold gelation of $\beta-\mathrm{lg}$ was achieved by various quantities of $1 \mathrm{~mol} \cdot \mathrm{L}^{-1}$ solution of $\mathrm{FeSO}_{4}$ to the WPI solutions previously heated by conventional heating and MEF. Heated and unheated (control) WPI solutions were mixed with different quantities of $\mathrm{FeSO}_{4}\left(1 \mathrm{~mol} \cdot \mathrm{L}^{-1}\right)$ solution (namely $10 \mathrm{mmol} \cdot \mathrm{L}^{-1}, 30 \mathrm{mmol} \cdot \mathrm{L}^{-1}$ and $50 \mathrm{mmol} \cdot \mathrm{L}^{-1}$ ) at room temperature 
$\left(25^{\circ} \mathrm{C}\right)$. It is known that $\mathrm{Fe}^{2+}$ concentrations ranging between $10 \mathrm{mmol} \cdot \mathrm{L}^{-1}$ and $40 \mathrm{mmol} \cdot \mathrm{L}^{-1}$ are able to produce auto-supported gels (Remondetto et al., 2002).

\subsection{Measurements}

\subsubsection{Particle size measurements}

Particle size measurements were performed through dynamic light scattering (DLS) using a Zetasizer Nano (ZEN 3600, Malvern Instruments Ltd., Malvern, U.K.) equipped with a He-Ne laser of $632.8 \mathrm{~nm}$ and $4 \mathrm{~mW}$. A Non-Invasive Back-Scatter (NIBS) detection system at $173^{\circ}$ was used to reduce the occurrence of scattering artifacts. The intensity-weighted mean particle diameter - $Z$-average $\left(Z_{d}\right)$ - and an estimate of the width of the distribution - polydispersity index (PdI) were derived from the cumulants analysis following Stokes-Einstein relationship (Anema \& Li, 2003). Intensity distribution of the scattered light was accessed and converted into volume weighted distribution using Mie theory (Nobbmann \& Morfesis, 2009). Measurements of unheated (control) and heated WPI solutions were carried out at least in triplicate (with three readings for each sample) using a dilution of 1:10 with distilled water. The temperature of the DLS cell was kept at $25 \pm 0.5^{\circ} \mathrm{C}$ during the measurements.

\subsubsection{Stability of WPI-based hydrogels}

Physical stability of the produced hydrogels was assessed through phase separation and size distribution changes $\left(\mathrm{Z}_{\mathrm{d}}\right)$, upon centrifugation at $10000 \mathrm{~g}$ for $5 \mathrm{~min}$ (Chen et al., 2006).

\subsubsection{Viscosity measurements}

Flow curves were determined using an Anton Paar Rheometer Physica MCR 300, with stainless steel and Titanium CC-10 concentric cylinder geometry, as described elsewhere (Anema, 2008; Sağlam, Venema, de Vries, Shi, \& van der Linden, 2013) with a diameter inner cylinder: $9.997 \mathrm{~mm}$; diameter cup: $10.845 \mathrm{~mm}$ and measuring cell TEK 150P-C. Viscosity of the produced hydrogels was measured as function of different shear rate (ranging from 800 to $1560 \mathrm{~s}^{-1}$ ) and also at constant shear rate of $1500 \mathrm{~s}^{-1}$. A Peltier element was used to maintain temperature at $25 \pm 1{ }^{\circ} \mathrm{C}$.

\subsubsection{Transmission electron microscopy imaging}

For transmission electron microscopy (TEM), WPI gels were imaged using a negative staining technique on a Zeiss EM 902A (Thornwood, N.Y., USA) microscope, at accelerating voltages of $50 \mathrm{kV}$ and $80 \mathrm{kV}$, as described elsewhere (Bourbon et al., 2015). A drop of liquid sample was deposited onto a carbon support film mounted on a copper grid. The excess product was removed after 2 min using a filter paper. The samples were negatively stained for $15 \mathrm{~s}$ by a droplet of an aqueous solution of $3 \%$ uranyl acetate and analyzed after natural drying at room temperature.

\subsection{Statistical analysis}

MEF effects on particle size of WPI hydrogels were assessed by response surface methodology (RSM) with two independent variables at three coded levels $(-1,0,+1)$. The independent variables were $\mathrm{E}_{\mathrm{F}}$ and $\mathrm{Fe}^{2+}$ concentration, while $\mathrm{Z}_{\mathrm{d}}$ was used as response or dependent variable. The desirability function analysis (DFA) derived from the RSM model was applied to estimate a desirability value, i.e. a measure of how close the fitted value is to a desired value within pre-established limits (Mang et al., 2015).

\section{Results and discussion}

\subsection{Cold gelation}

Fig. 1(a, b and c) shows size characterization through DLS of protein aggregates from unheated (control) and heated $\left(90^{\circ} \mathrm{C}\right.$ for $5 \mathrm{~min}$ ) WPI solutions after addition of $\mathrm{Fe}^{2+}$ at room temperature $\left(25^{\circ} \mathrm{C}\right)$. The heating step, together with addition of $\mathrm{Fe}^{2+}$ increase the time at which autocorrelation function - a dynamic measure of the scattered light of protein particles in solution - starts to decay (Fig. 1a). This extended decay is intrinsically related to the presence of larger protein aggregates in solution (Pullara et al., 2013). However, the presence of an electric field $\left(\mathrm{E}_{\mathrm{F}}\right.$ of $\left.10 \mathrm{~V} \cdot \mathrm{cm}^{-1}\right)$ during heating seemed to quench emergence of these large aggregates. This was also apparent from the resulting volume size distribution of the produced hydrogels (Fig. 1b).

Particle size distributions looked bimodal, a common feature of whey processed ingredients, such as whey protein concentrate (WPC) or WPI. Fig. 1b) shows that two particle size populations characterize unheated WPI (control); a first, and also most representative one (with $92 \%$ of the total distribution), ranging from $4 \mathrm{~nm}$ to $14 \mathrm{~nm}$, which corresponds to monomers and dimers of native $\beta$-lg and $\alpha$-lac (Gimel, Durand, \& Nicolai, 1994; Nicorescu et al., 2008; Rodrigues et al., 2015; Roefs \& De Kruif, 1994); and a second one (with $8 \%$ of the total distribution) between $15 \mathrm{~nm}$ and $70 \mathrm{~nm}$, related with native whey aggregates (Nicorescu et al., 2008).

Cold gels prepared from heated WPI at $0 \mathrm{~V} \cdot \mathrm{cm}^{-1}$ shifted the size distribution towards larger particles, and were characterized also by two peaks: one small peak between $37 \mathrm{~nm}$ and $220 \mathrm{~nm}$, representing $27 \%$ of the total distribution; and a larger one between $250 \mathrm{~nm}$ and $2000 \mathrm{~nm}$, representing 73\% of the total distribution. These results indicated not only protein aggregation imposed by the thermal treatment but also, and to a greater extent, the hydrogel network formation governed by $\mathrm{Fe}^{2+}$ addition. Hydrogels prepared under MEF resulted also in a bimodal size distribution, but in this case, the shift towards large particles was less favored. Higher volumes of particles, with $72 \%$ of the total size distribution, were found between $20 \mathrm{~nm}$ and $90 \mathrm{~nm}$, while the remaining $28 \%$ presented sizes ranging from $106 \mathrm{~nm}$ to $825 \mathrm{~nm}$. Fig. 1c shows $\mathrm{Fe}^{2+}$ dependent changes in the $\mathrm{Z}_{\mathrm{d}}$ of WPI solutions, thus confirming the influence of MEF on the protein aggregation phenomena after and before the cold gelation process. The heating step per se was essential to bring about enough molecular unfolding in the protein structure and further aggregation; an increase in $Z_{d}$ from $45 \mathrm{~nm}$ (control) to $90 \mathrm{~nm}$ and $130 \mathrm{~nm}$ was observed at $E_{F}$ of $10 \mathrm{~V} \cdot \mathrm{cm}^{-1}$ and $0 \mathrm{~V} \cdot \mathrm{cm}^{-1}$, respectively. These aggregates are the unit "blocks" that will be needed to develop a WPI gel network and impose a certain rheological response from the gel (Kavanagh, Clark, \& Ross-Murphy, 2000; Pereira et al., 2015). Increasing concentration of $\mathrm{Fe}^{2+}$ from $10 \mathrm{mmol} \cdot \mathrm{L}^{-1}$ to $50 \mathrm{mmol} \cdot \mathrm{L}^{-1}$ in all WPI heated solutions resulted in an increase of $\mathrm{Z}_{\mathrm{d}}$ due to cold gelation and formation of a hydrogel network. These results corroborate those reported elsewhere (Remondetto et al., 2002; Remondetto et al., 2004) showing that heatdenatured proteins, when below their critical concentration, aggregate upon addition of such divalent cations as $\mathrm{Fe}^{2+}$. In agreement with Fig. 1c, application of MEF impaired formation of larger protein aggregates at $\mathrm{Fe}^{2+}$ concentrations above $10 \mathrm{mmol} \cdot \mathrm{L}^{-1}$. For example, at $\mathrm{Fe}^{2+}$ concentration of $50 \mathrm{mmol} \cdot \mathrm{L}^{-1}$, a maximum $\mathrm{Z}_{\mathrm{d}}$ value of $164 \mathrm{~nm}$ was observed at $E_{F}$ of $10 \mathrm{~V} \cdot \mathrm{cm}^{-1}$, while heating treatments at $0 \mathrm{~V} \cdot \mathrm{cm}^{-1}$ resulted in a $Z_{\mathrm{d}}$ of $204 \mathrm{~nm}$.

Addition of $\mathrm{Fe}^{2+}$ to unheated WPI (control) also led to a significant increase of $Z_{d}$, yet this can be explained by presence of small amounts of denatured protein interacting with $\mathrm{Fe}^{2+}$ and thus forming aggregates, as confirmed by inspection of Fig. 1b. Despite a sharp increase in particle size, the polydispersity index (PdI) for all WPI samples resulting from cumulant analysis remained barely constant between 0.3 and 0.6 (results not shown) - a range over which the algorithms to evaluate the size distribution of polydisperse solutions are still accurate.

\subsection{MEF effects}

To obtain a better insight about the influence of MEF on production of WPI hydrogels, thermally denaturated WPI solutions produced at 

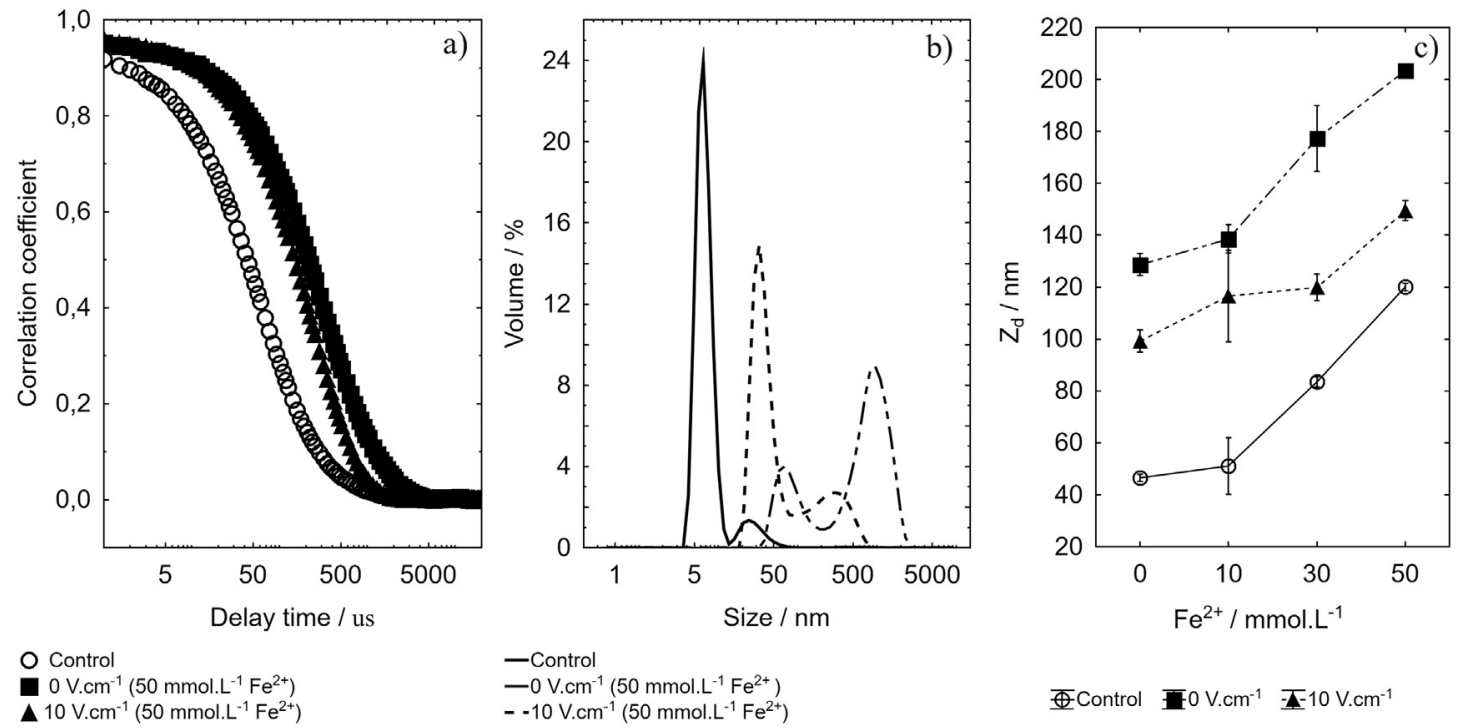

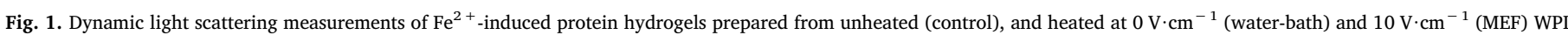
solutions: a) autocorrelation curve; b) particle size distribution by volume; and c) $Z$-average diameter $\left(\mathrm{Z}_{\mathrm{d}}\right)$ of protein particles.

different $\mathrm{E}_{\mathrm{F}}$ (ranging from $0 \mathrm{~V} \cdot \mathrm{cm}^{-1}$ to $10 \mathrm{~V} \cdot \mathrm{cm}^{-1}$ ) were combined with increasing concentrations of $\mathrm{Fe}^{2+}$ (from $0 \mathrm{mmol} \cdot \mathrm{L}^{-1}$ to $\left.50 \mathrm{mmol} \cdot \mathrm{L}^{-1}\right)$ at room temperature $\left(25^{\circ} \mathrm{C}\right)$. A RSM was used to fit all the results obtained, evaluate its statistical significance and optimize $\mathrm{E}_{\mathrm{F}} / \mathrm{Fe}^{2+}$ variables for production of WPI hydrogels taking into account the conditions tested in this study.

The response variable - i.e. particle size represented by $Z_{d}$ - to the independent variables $\left(\mathrm{E}_{\mathrm{F}}\right.$ and $\mathrm{Fe}^{2+}$ ) was fitted via a second order model (with linear/quadratic effects), as shown by Eq. 1. The model robustness and suitability was evaluated by using analysis of variance ANOVA (Table 1).

$$
\begin{aligned}
\mathrm{Z}_{\mathrm{D}}\left(\mathrm{E}_{\mathrm{F}},\left|\mathrm{Fe}^{2+}\right|\right)= & 134.59-10.24 \cdot \mathrm{E}_{\mathrm{F}}+0.65 \cdot\left(E_{\mathrm{F}}\right)^{2}+1.08 \cdot\left|F e^{2+}\right| \\
& +0.0018 \cdot\left(\mid F e^{2+\mid}\right)^{2}
\end{aligned}
$$

Table 1 shows that the lack of fit test was not statistically significant $(p<0.05)$, while the determination coefficient $\left(R^{2}\right)$ was high and RMSE low ( $<10 \%$ of the range of target property value), thus suggesting that the linear and quadratic model fit well the data (Alexander, Tropsha, \& Winkler, 2015). The bias value was low $(<0.001)$ and coefficient of variation was $4.7 \%$, thus giving the indication of a low degree of variability and good precision of the data from the 32 experiments. Linear effects of $\mathrm{E}_{\mathrm{F}}$ and $\mathrm{Fe}^{2+}$ were both extremely significant $(p<0.0001)$, while quadratic effects appeared to be very significant in the case of MEF $(p<0.001)$ but not statistically significant $(p>0.05)$ in the case of $\mathrm{Fe}^{2+}$. These results made it clear that

Table 1

Analysis of variance (ANOVA) for response surface second order model with quadratic $(\mathrm{Q})$ and linear $(\mathrm{L})$ effects of electric field intensity $\left(\mathrm{E}_{\mathrm{F}}\right)$ and divalent iron $\left(\mathrm{Fe}^{2+}\right)$ used to predict particle size $\left(\mathrm{Z}_{\mathrm{d}}\right)$ changes.

\begin{tabular}{llllll}
\hline Factor & SS & DF & MS & F & $p$-value \\
\hline $\mathrm{E}_{\mathrm{F}}(\mathrm{L})$ & 7135.15 & 1 & 7135.15 & 90.53 & $<0.00010$ \\
$\mathrm{E}_{\mathrm{F}}(\mathrm{Q})$ & 1275.06 & 1 & 1275.06 & 16.18 & 0.00067 \\
$\mathrm{Fe}^{2+}(\mathrm{L})$ & $14,404.00$ & 1 & $14,404.00$ & 182,76 & $<0.00010$ \\
$\mathrm{Fe}^{2+}(\mathrm{Q})$ & 6.10 & 1 & 6.10 & 0.078 & 0.78 \\
Lack-of-fit & 1271.32 & 7 & 181.62 & 2.30 & 0.068 \\
Error & 1576.23 & 20 & 78.81 & & \\
Total SS & $25,034.56$ & 31 & & & \\
\hline
\end{tabular}

RMSE $=8.9$.

$R^{2}=0.89$ ( 32 runs; $\mathrm{CV}=4.73 \%$ ).

SS, sum of the squares; DF, degrees of freedom; MS, mean sum of the squares; F, Fstatistic; and $p$, Prob > F).

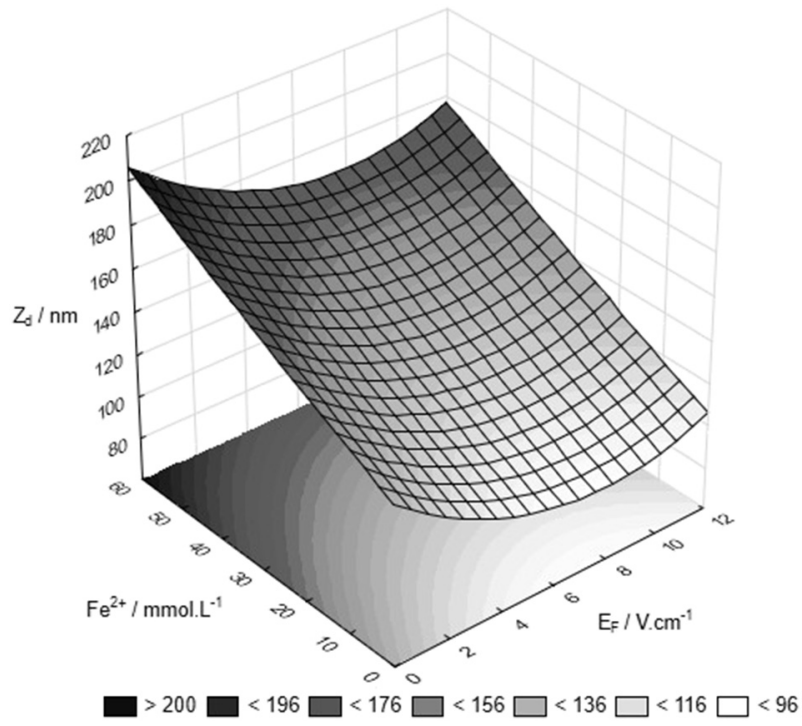

Fig. 2. Effects of electric field strength applied during heating treatment (at $90{ }^{\circ} \mathrm{C}$ for 5 min) and $\mathrm{Fe}^{2+}$ concentration upon particle size $\left(\mathrm{Z}_{\mathrm{d}}\right)$ of produced WPI hydrogels.

cold gelation and development of a gel matrix are intimately related with thermal denaturation and aggregation under MEF influence. Fig. 2 shows that $\mathrm{E}_{\mathrm{F}}$ at low range (between $2 \mathrm{~V} \cdot \mathrm{cm}^{-1}$ and $6 \mathrm{~V} \cdot \mathrm{cm}^{-1}$ ) causes a linear decrease in particle size of the produced hydrogels, while $\mathrm{E}_{\mathrm{F}}$ above $10 \mathrm{~V} \cdot \mathrm{cm}^{-1}$ combined with high $\mathrm{Fe}^{2+}$ concentrations can lead to a quadratic increase in particle size. However, conventional heating (treatments at $0 \mathrm{~V} \cdot \mathrm{cm}^{-1}$ ) produces always a higher particle size increase, irrespective of the $\mathrm{Fe}^{2+}$ concentration used. These results highlight the importance of WPI aggregates upon cold gelation and properties of the produced WPI gels, particularly the influence of MEF on aggregation kinetics and type of aggregates obtained. It has recently been reported that MEF reduces the magnitude of protein aggregation by giving rise to protein particles with a linear or fibrillar shape and/or impairing the onset of protein aggregation due to volumetric heating and electrical conformational disturbances (Pereira et al., 2015).

\subsection{Enhancing stability of WPI hydrogels}

Use of $\mathrm{Fe}^{2+}$ below $10 \mathrm{mmol} \cdot \mathrm{L}^{-1}$ is known to have negligible effect 


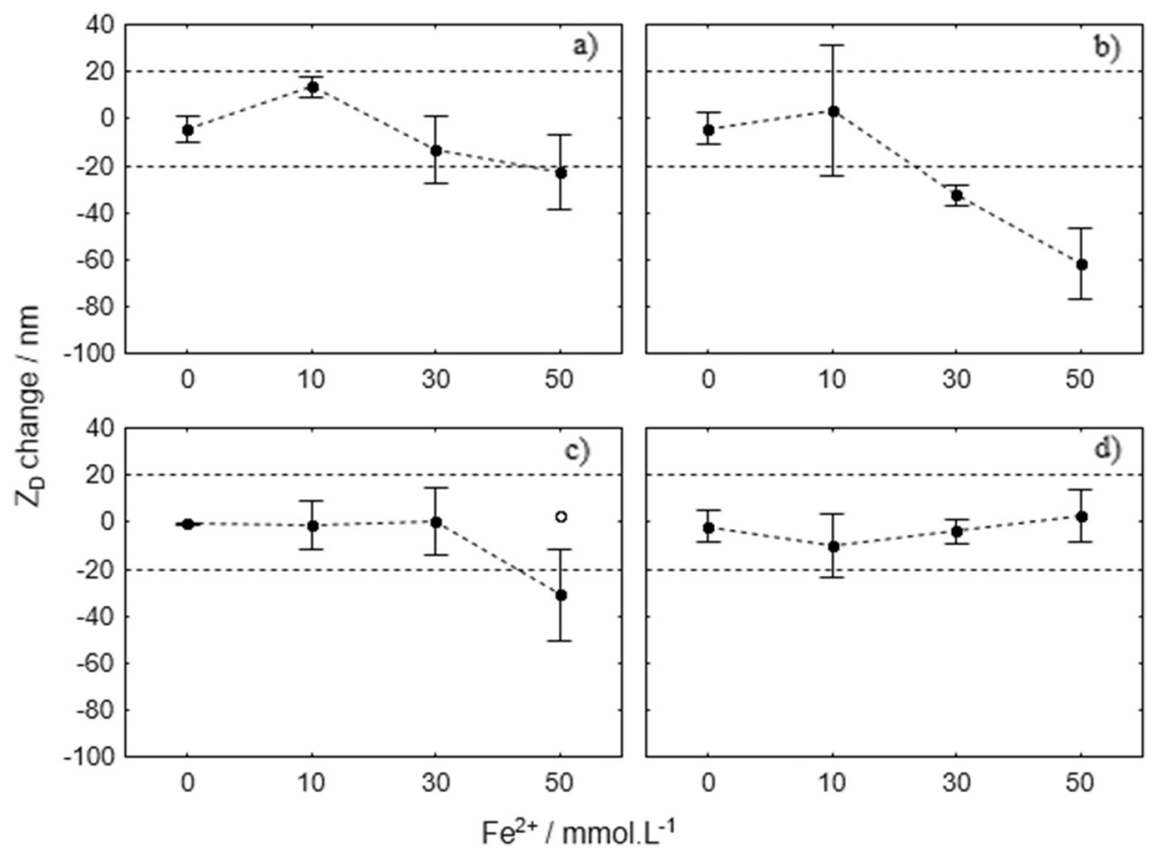

Fig. 3. Effects of $\mathrm{Fe}^{2+}$ concentration upon physical stability (decrease of $\mathrm{Z}_{\mathrm{d}}$ ) of unheated (a) and heated WPI at $90^{\circ} \mathrm{C}(5 \mathrm{~min})$ under $0 \mathrm{~V} \cdot \mathrm{cm}^{-1}$ (b), $3 \mathrm{~V} \cdot \mathrm{cm}^{-1}$ (c) and $10 \mathrm{~V} \cdot \mathrm{cm}^{-1}$ (d) treatments.

on gelation, while concentrations above $40 \mathrm{mmol} \cdot \mathrm{L}^{-1}$ may produce particulate or random gels more prone to syneresis (Remondetto et al., 2002; Remondetto \& Subirade, 2003). Fig. 3 shows $Z_{d}$ decrease after centrifugation of the various hydrogels produced. The observed decrease of $Z_{d}$ was a measure of gel instability resulting from the disruption of hydrogel protein network, and consequent water separation and sedimentation of protein aggregates, due to particle movement during centrifugation. Hydrogel instability was evaluated as a function of $\mathrm{Fe}^{2+}$ concentration and electrical treatment applied (intensity of electric field). Hydrogels produced from unheated WPI were less stable above $30 \mathrm{mmol} \cdot \mathrm{L}^{-1}$ of $\mathrm{Fe}^{2+}$. This effect was even clearer in WPI hydrogels produced via conventional heating treatments (Fig. $3 \mathrm{~b}$ ), where $30 \mathrm{mmol} \cdot \mathrm{L}^{-1}$ and $50 \mathrm{mmol} \cdot \mathrm{L}^{-1}$ of $\mathrm{Fe}^{2+}$ induced a decrease of $\mathrm{Z}_{\mathrm{d}}$ of ca. $30 \mathrm{~nm}$ and $60 \mathrm{~nm}$, respectively. Hydrogels produced by MEF appeared much more stable, with small measurement variability $(<20 \mathrm{~nm})$. Moreover, this stability was strongly correlated with the intensity of MEF applied; for treatments at $3 \mathrm{~V} \cdot \mathrm{cm}^{-1}$ (Fig. 3c) separation of phases and correspondent size decrease was only visible at $50 \mathrm{mmol} \cdot \mathrm{L}^{-1}$ of $\mathrm{Fe}^{2+}$; while at $10 \mathrm{~V} \cdot \mathrm{cm}^{-1}$, WPI hydrogels maintained their integrity $\left(\mathrm{Z}_{\mathrm{d}}\right.$ remained stable) independently of $\mathrm{Fe}^{2+}$ concentration.

The gel network developed during the cold gelation step was intrinsically related to the ability of tuning WPI aggregation during heating and MEF treatment. WPI solutions with higher size aggregates resulted in less stable hydrogels upon centrifugation. Results in Figs. 2 and 3 allowed defining the desirable limits of MEF intensity and $\mathrm{Fe}^{2+}$ concentrations to produce stable hydrogels - taking into consideration the size distribution of protein particles. The best compromise between $\mathrm{Fe}^{2+}$ concentration and MEF intensity for production of stable WPI hydrogels with a well-defined size range distribution was then estimated through a desirability function approach - DFA (Derringer \& Suich, 1980). Fig. 4 shows desirability levels and limits based on the mathematical model constructed in RSM. The desirability ranged from zero to one; zero indicates responses outside of desirable limit previously established, while a unit desirability value is considered to be the optimal case (Li et al., 2007; Mang et al., 2015).

Desirability limits were established based on DLS measurements from the hydrogels which were less stable or more prone to disruption (i.e. with $Z_{d}$ variations larger than $20 \mathrm{~nm}$ upon centrifugation). Less resistant hydrogels were characterized by a higher PdI $(>0.5)$ and a $Z_{d}$ and volume mean of ca. $200 \mathrm{~nm}$ and $500 \mathrm{~nm}$, respectively. Through DFA it was possible to conclude that optimal conditions for production of stable WPI hydrogels are attained when a heating treatment with a MEF of $3 \mathrm{~V} \cdot \mathrm{cm}^{-1}$ is combined with a cold gelation step using $33 \mathrm{mmol} \cdot \mathrm{L}^{-1}$ of $\mathrm{Fe}^{2+}$. Under these conditions it is possible to obtain a high desirability value (of 0.78 ) and WPI hydrogels with a $Z_{d}$ of $145 \mathrm{~nm}$, volume mean of $240 \mathrm{~nm}$ and PdI of 0.335 . The surface plot derived from DFA (see Fig. 4) also discloses that high concentrations of $\mathrm{Fe}^{2+}$ (ranging from $30 \mathrm{mmol} \cdot \mathrm{L}^{-1}$ to $50 \mathrm{mmol} \cdot \mathrm{L}^{-1}$ ) can be incorporated in WPI hydrogels without compromising their desirable size properties, and thus physical stability, when MEF treatments of $3 \mathrm{~V} \cdot \mathrm{cm}^{-1}$ to $10 \mathrm{~V} \cdot \mathrm{cm}^{-1}$ are applied.

\subsection{Viscosity}

WPI hydrogels were produced at $33 \mathrm{mM}$ of $\mathrm{Fe}^{2+}$ using different MEF intensities during the pre-denaturation treatment $\left(0 \mathrm{~V} \cdot \mathrm{cm}^{-1}\right.$, $3 \mathrm{~V} \cdot \mathrm{cm}^{-1}$ and $10 \mathrm{~V} \cdot \mathrm{cm}^{-1}$ ). This allowed the viscosity of WPI hydrogels to be studied at the optimal combination of MEF and $\mathrm{Fe}^{2+}$ concentration previously found (i.e. $\mathrm{E}_{\mathrm{F}}$ at $3 \mathrm{~V} \cdot \mathrm{cm}^{-1}$ combined with cold gelation at $33 \mathrm{mmol} \cdot \mathrm{L}^{-1} \mathrm{Fe}^{2+}$ ), and compared with absence and higher MEF treatment intensities (used as negative and positive control, respectively). The shear viscosity function of shear rate of the different WPI treated solutions are represented in Fig. 5a-b. Overall WPI cold-set hydrogels presented a low viscosity $\left(<1 \times 10^{-2} \mathrm{~Pa} \cdot \mathrm{s}\right)$ which impaired measurements at low shear-rates due to surface tension artifacts (Ewoldt, Johnston, \& Caretta, 2015). To avoid artifacts, data points were only taken from the measurement at high shear-rates, ensuring that the measured torque values exceeded the minimum torque value of the rheometer $\left(1 \times 10^{-6} \mathrm{Nm}\right)$, in accordance to the method described by Akkermans et al. (Akkermans, Van der Goot, Venema, Van der Linden, \& Boom, 2008). As expected addition $\mathrm{Fe}^{2+}$ increased significantly viscosity of solutions suggesting the entanglement of denaturated protein chains and thus corroborating previous observations from size particle analysis and published literature (Martin \& Jong, 2012; Remondetto et al., 2002; Remondetto \& Subirade, 2003). Independently of $\mathrm{Fe}^{2+}$ addition, the viscosity of MEF treated solutions was significantly lower $(p<0.05)$ when compared with those treated by conventional heating. This evidence the fact that the impairment of protein aggregation observed at nano-scale after MEF treatment was noteworthy thus affecting mechanical properties of the produced WPI hydrogels.

Whey protein solutions pre-heated at high temperatures and longer 

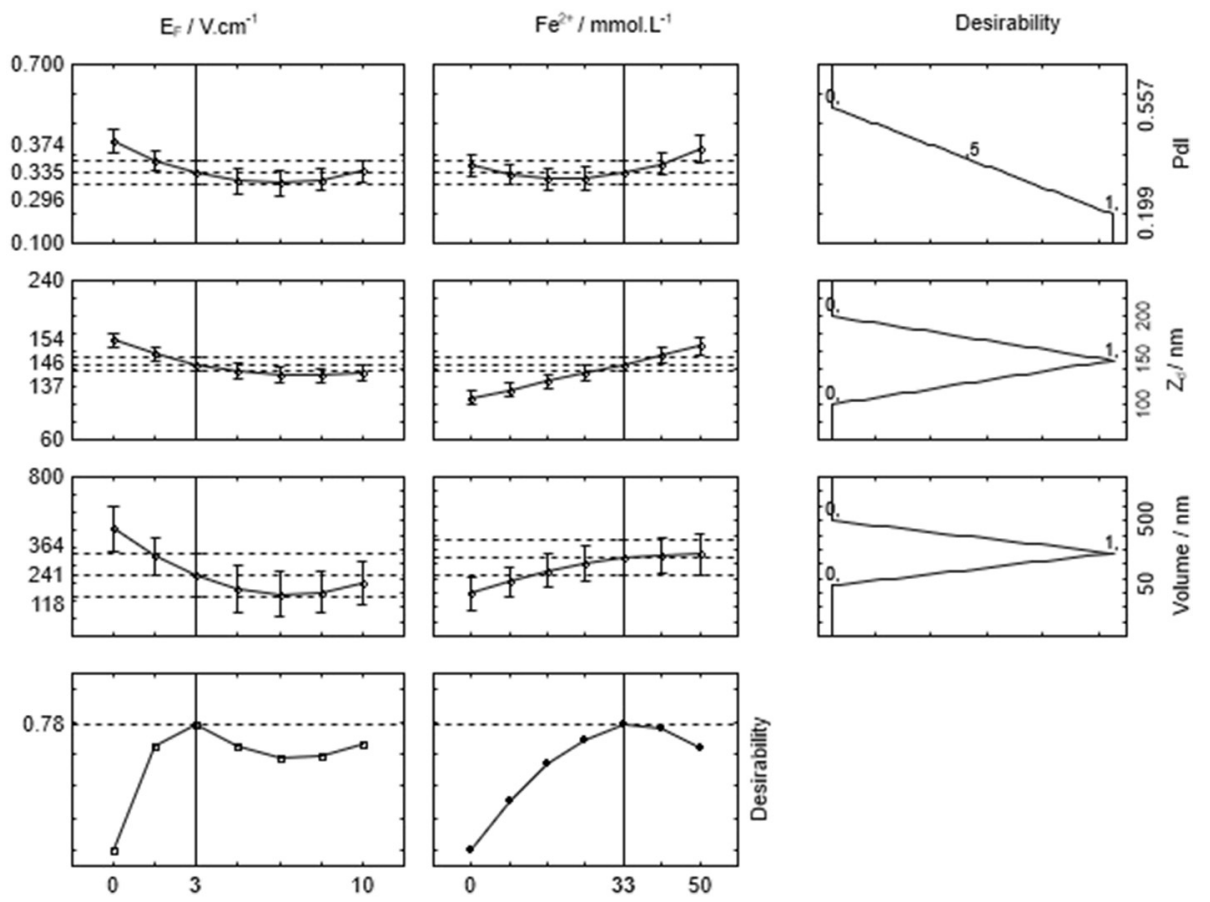

Fig. 4. Desirability values of particle size under the effects of different MEF intensity $\left(0 \mathrm{~V} \cdot \mathrm{cm}^{-1}, 3 \mathrm{~V} \cdot \mathrm{cm}^{-1}\right.$ and $\left.10 \mathrm{~V} \cdot \mathrm{cm}^{-1}\right)$ and $\mathrm{Fe}^{2+}$ concentrations $\left(0 \mathrm{mmol} \cdot \mathrm{L}^{-1}\right.$, $10 \mathrm{mmol} \cdot \mathrm{L}^{-1}, 30 \mathrm{mmol} \cdot \mathrm{L}^{-1}$ and $50 \mathrm{mmol} \cdot \mathrm{L}^{-1}$ ).
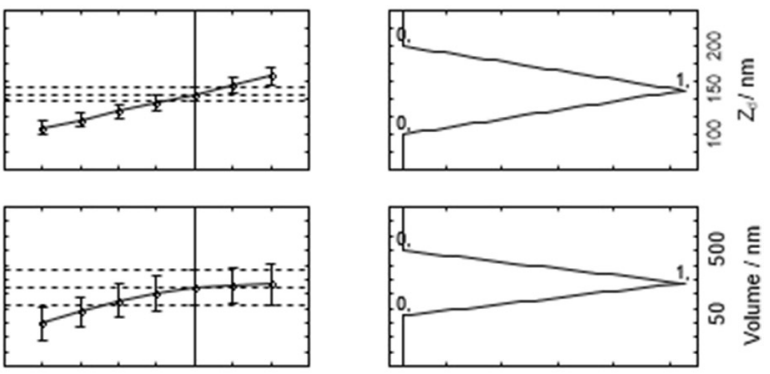

heating times can be characterized by a shear-thinning or Newtonian behavior. After cold-set gelation whey protein gels can be manipulated or designed to be used as food thickeners (Hudson, Daubert, \& Foegeding, 2000; Resch, Daubert, \& Foegeding, 2005; Ruben \& Sundaram, 2009). To understand the flow behavior of the fluid sample the power-law model was adjusted to the experimental data obtained through Eq. 2 (Eq. 2):

$\sigma=k \cdot \gamma^{n}$

where $\sigma$ is shear stress $(\mathrm{Pa}), \gamma$ is shear rate $\left(\mathrm{s}^{-1}\right), k$ is consistency index $\left(\mathrm{Pa} \cdot \mathrm{s}^{\mathrm{n}}\right)$, and $n$ is flow or power-law index. Fig. 6 shows typical flow curves of shear stress as function of shear rate, as well as predicted shear stress values based on the power-law model (Eq. 2). The corresponding model parameters are summarized in Table 2.

The correlation coefficients of model fitting to experimental data (a)

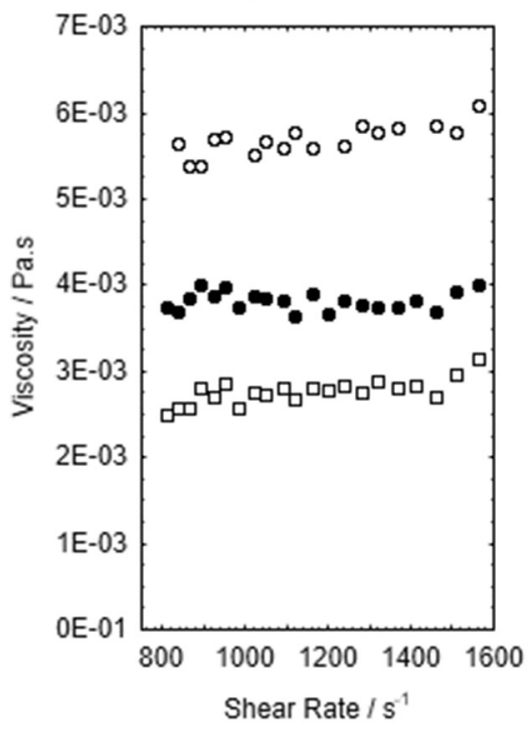

(b)

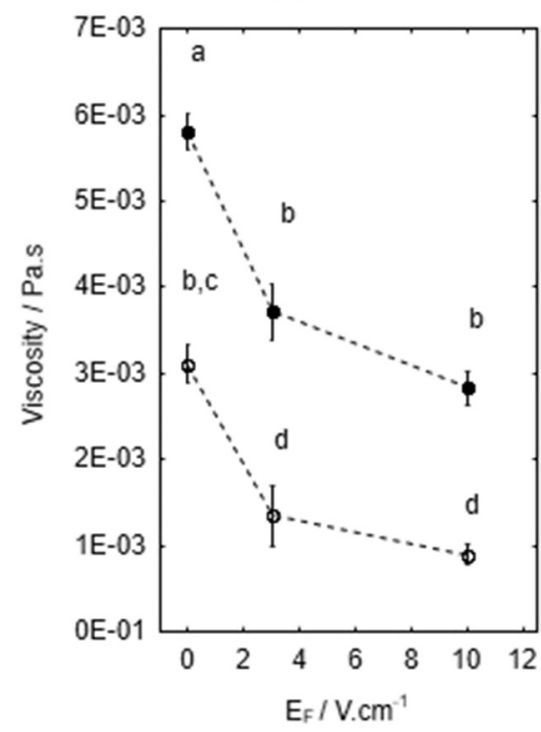

were considerably high (in all cases $>0.96$ ). Hydrogels produced presented a typical Newtonian behavior with $n$ ranging from 0.98 to 1.3. This behavior was somehow expected, once diluted biopolymer solutions often show a typical Newtonian flow (Tecante, 2009) due to the prevalence of protein-solvent interactions over protein-protein interactions. However, $n$ value seems to increase with increasing MEF intensity in particular at $10 \mathrm{~V} \cdot \mathrm{cm}^{-1}$ suggesting that a shear-thickening behavior may occur with other experimental conditions (i.e. increase protein concentration in solution). A relevant trend was observed for the $k$ value thus confirming the different viscosity patterns between samples; conventional treatments (at $0 \mathrm{~V} \cdot \mathrm{cm}^{-1}$ ) led to a $k$ value of 2 and 10 times higher than treatments at $3 \mathrm{~V} \cdot \mathrm{cm}^{-1}$ and $10 \mathrm{~V} \cdot \mathrm{cm}^{-1}$, respectively (see Table 2).

It has been recently reported that ohmic heating and its MEF can impair protein aggregation as well as gelation, due to development
Fig. 5. Viscosity of hydrogels produced at $33 \mathrm{mmol} \cdot \mathrm{L}^{-1}$ of $\mathrm{Fe}^{2+}$ as function of different shear rate (a) and plotted versus electric field intensity at shear rate of $1500 \mathrm{~s}^{-1}$ at $0 \mathrm{mmol} \cdot \mathrm{L}^{-1}$ and $33 \mathrm{mmol} \cdot \mathrm{L}^{-1}$ of $\mathrm{Fe}^{2+}$ (b). Lines only provided to eye guidance.

○ 0 V.cm ${ }^{-1} \bullet 3$ V.cm- ${ }^{-1}$ व 10 V.cm ${ }^{-1}$

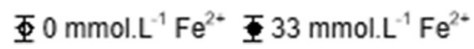




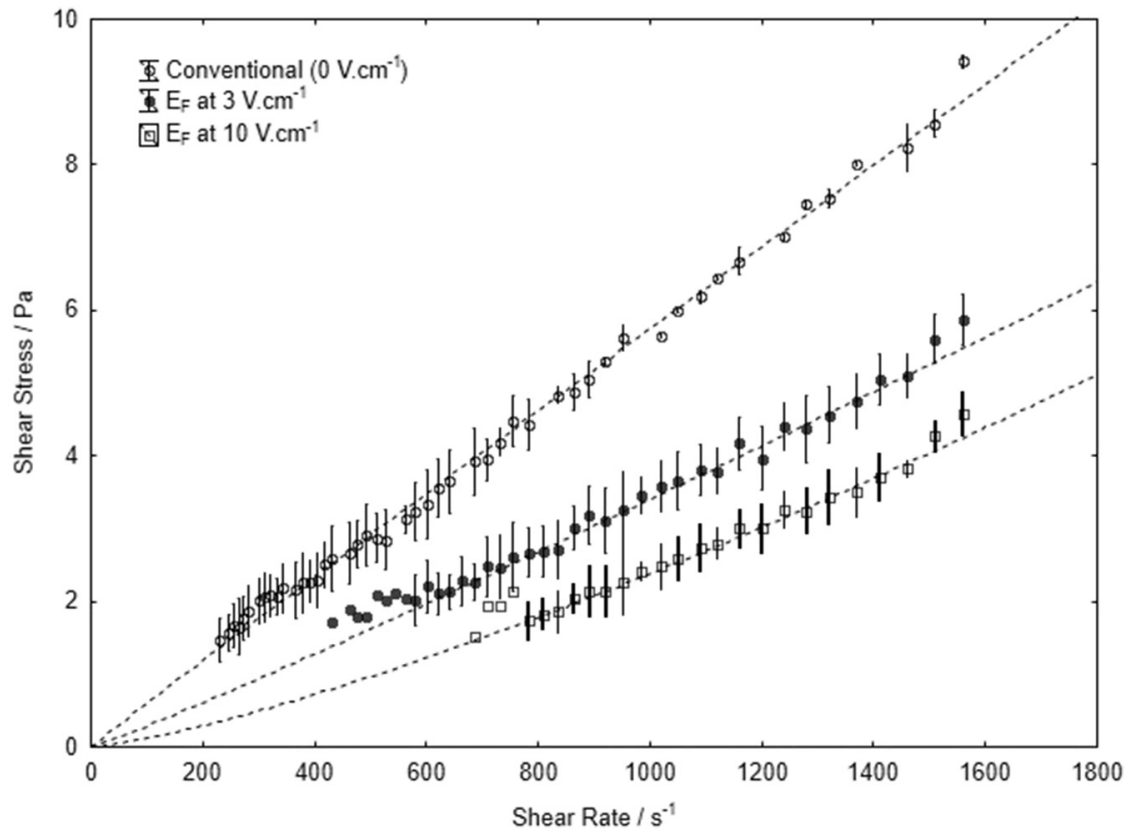

Fig. 6. Flow curves of WPI hydrogels produced under different MEF intensities with $33 \mathrm{mmol} \cdot \mathrm{L}^{-1}$ of $\mathrm{Fe}^{2+}$ where, dashed lines correspond to experimental data fitting assuming the power law model.
Table 2

Power law parameters for WPI hydrogels produced at different MEF treatments.

\begin{tabular}{lllll}
\hline \multirow{2}{*}{ Treatment } & \multicolumn{2}{l}{ Model parameters } & & \\
\cline { 2 - 5 } & $k\left(\mathrm{~Pa} \cdot \mathrm{s}^{\mathrm{n}}\right)$ & $\mathrm{n}$ & $R^{2}$ & RMSE \\
\hline $0 \mathrm{~V} \cdot \mathrm{cm}^{-1}$ & $6.6 \cdot 10^{-3} \pm 5.0 \cdot 10^{-4}$ & $0.98 \pm 0.01$ & 0.998 & 0.130 \\
$3 \mathrm{~V} \cdot \mathrm{cm}^{-1}$ & $2.1 \cdot 10^{-3} \pm 3.0 \cdot 10^{-4}$ & $1.07 \pm 0.02$ & 0.989 & 0.112 \\
$10 \mathrm{~V} \cdot \mathrm{cm}^{-1}$ & $3.0 \cdot 10^{-4} \pm 6.3 \cdot 10^{-5}$ & $1.32 \pm 0.03$ & 0.988 & 0.086 \\
\hline
\end{tabular}

Note: $k$, consistency index; RMSE, root mean square error.

short fibrillar aggregates in WPI solutions (Pereira et al., 2015). Reduced aggregation and the presence of short fibrils seem to be intrinsically related and these events can be used to explain the flow behavior and consistency of the protein solutions observed in this study. It has been recently reported that at acidic $\mathrm{pH}$, the presence of an electric field during thermal protein denaturation may disturb noncovalent interactions between unfolded/denaturated whey proteins subunits, thus giving rise to a so-called "progel state" where the viscous modulus is not superimposed by the elastic modulus during small amplitude oscillatory dynamic measurements (Rodrigues et al., 2015). The low consistency of hydrogels under the effects of MEF may be the consequence of this progel state.

\subsection{Microstructure}

The microstructure of WPI hydrogels produced at optimal conditions of $\mathrm{Fe}^{2+}$ and $\mathrm{MEF}$ intensity (i.e. $33 \mathrm{mmol} \cdot \mathrm{L}^{-1}$ and $3 \mathrm{~V} \cdot \mathrm{cm}^{-1}$, respectively) was evaluated through TEM. Fig. 7 displays heated WPI (a-b) solutions as well as WPI hydrogels produced after the cold gelation step (c-d). Heated WPI solutions clearly indicate that protein aggregates are composed of a network of fibrils. This fibrillar structure is expected to occur at heating conditions under which intermolecular electrostatic interactions take part - i.e. at low ionic strength and $\mathrm{pH}$ values, far from the isoelectric point of $\beta$-lg, i.e. 5.2 (Ikeda \& Morris, 2002; Pereira et al., 2015; Ramos, Pereira, Rodrigues, Teixeira, Vicente, \& Xavier Malcata, 2014).

Ohmic heating and its MEF have been associated with formation of $\beta$-lg fibrils due to conformational disturbances and changes of protein's secondary structures, namely increasing the contents of $\beta$-sheet structures (Kavanagh et al., 2000; Pereira et al., 2015; Pereira et al., 2010).
Conventional heating gave rise to a thread of filaments in a well-defined compact structure. While TEM micrographs of $\mathrm{OH}$ treatments at $3 \mathrm{~V} \cdot \mathrm{cm}^{-1}$ evidenced protein aggregates but in a much more disordered way, as well as the existence of dispersed short fibrils. These fibrillar structures may have contributed for a lower particle size distribution observed during DLS measurements, as described elsewhere (Pereira et al., 2015). Addition of $33 \mathrm{mmol} \cdot \mathrm{L}^{-1}$ of $\mathrm{Fe}^{2+}$ changed significantly the appearance of TEM micrographs. Both WPI hydrogels pre-treated at $0 \mathrm{~V} \cdot \mathrm{cm}^{-1}$ (Fig. $7 \mathrm{c}$ ) and $3 \mathrm{~V} \cdot \mathrm{cm}^{-1}$ (Fig. $7 \mathrm{~d}$ ) possess more a filamentous microstructure rather than a particulate or random one. Filamentous network establishment is unlikely to happen when [iron]/[protein] ratio is high (Remondetto et al., 2002), but the level of protein aggregation should not be underestimated in this case. Heating conditions and levels of protein aggregation change the role of electrostatic interactions with $\mathrm{Fe}^{2+}$, as discussed in the previous sections. Cold set hydrogels produced at $3 \mathrm{~V} \cdot \mathrm{cm}^{-1}$ gave rise to a more homogenous and compact structure, while treatments $0 \mathrm{~V} \cdot \mathrm{cm}^{-1}$ possessed a nonhomogeneous and open microstructure with large and irregular pores. By interfering with protein aggregation pathways (i.e. reducing aggregation or changing aggregates shape) MEF rendered whey proteins more available to interact with $\mathrm{Fe}^{2+}$, thus resulting in a higher compactness of the hydrogel structure.

\subsection{Nutritional aspects}

Iron deficiency is one of the most common nutrient deficiency and prevalent cause of anemia worldwide (Powers \& Buchanan, 2014; Alibabić et al., 2016). In particular, young women are at greater risk of anemia due pregnancy and losses from menstruation and childbirth (World Health Organization, 2001). Recommended intakes of iron depends on its bioavailability across different diets, as well as on it levels among populations (Beck, 2015). Overall, depending on age, gender group and bioavailability of iron, the recommended iron intakes to cover requirements of $97.5 \%$ of populations can range from $3 \mathrm{mg} /$ day (as case of children of 1 to 3 years with 15\% of iron absorption) up to $65 \mathrm{mg} /$ day (case of young female of 11 to 14 years with 5\% iron absorption) (World Health Organization, 2001). In this study, through the use of ferrous sulfate it was possible to incorporate about $33 \mathrm{mmol} \cdot \mathrm{L}^{-1}$ of $\mathrm{Fe}^{2+}$ in the produced protein network. This means that a daily dose of $5 \mathrm{ml}$ (a teaspoon) of the produced hydrogel would be equivalent to an iron intake of $9 \mathrm{mg} /$ day. Iron from ferrous sulfate is highly water- 


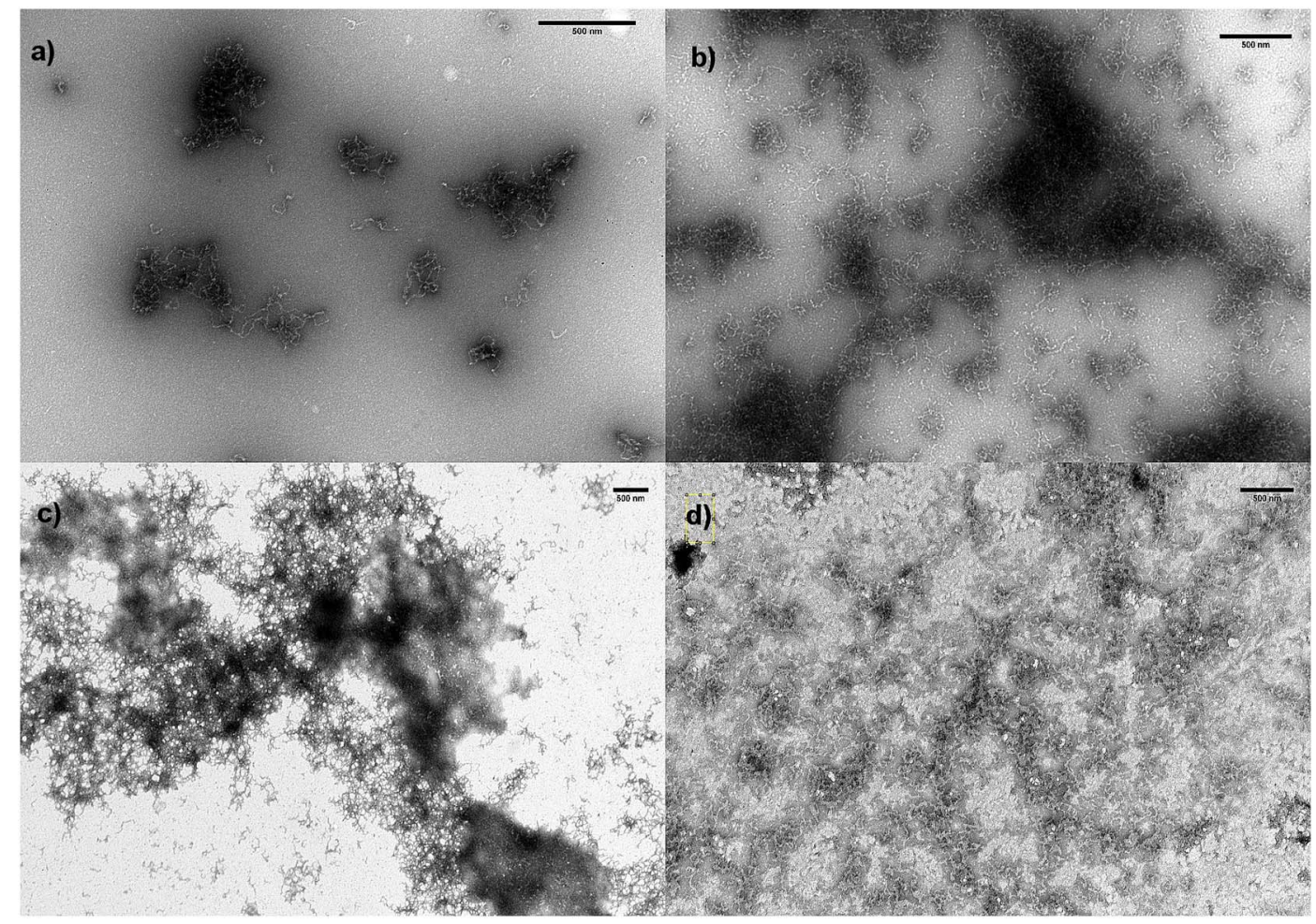

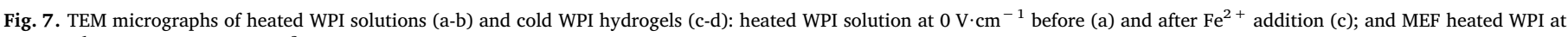
$3 \mathrm{~V} \cdot \mathrm{cm}^{-1}$ before (b) and after $\mathrm{Fe}^{2+}$ addition (d). All scale bars correspond to a size of $500 \mathrm{~nm}$.

soluble and bioavailable and thus desirable to be used as food, as well as widely accepted by the medical community (Powers \& Buchanan, 2014; Oski, 1993). Furthermore, whey protein present itself unique functional, nutritional and biological properties that turns their incorporation in diet widely and comprehensively recognized (Patel, 2015). For all these reasons, the produced whey protein hydrogels fortified with iron offers a great potential to be used as an oral dietary supplement.

\section{Conclusions}

Application of electric fields changes how whey proteins aggregate during ohmic heating, thus influencing the outcome of the cold gelation process assisted by $\mathrm{Fe}^{2+}$. The passage of alternating electrical current at certain frequencies may impose conformational disturbances of tertiary and secondary protein structures, reorientation of proteins' hydrophobic core and screen electrostatic or other kind of non-covalent protein interactions. Nevertheless, the molecular mechanisms underlying relationships between protein structure and electrical variables (such as electric field, electrical current and frequency) still remain speculative. Undoubtedly, the size or extent of whey protein aggregation can be modulated depending on the intensity of the electric field applied. Our results reveal that an integrated strategy that combines electrical-heating (as denaturation pre-treatment) with cold gelation (mediated by $\mathrm{Fe}^{2+}$ ) can be used to control microstructure and macroscopic properties of whey protein hydrogels. By controlling the balance between levels of unfolded and aggregated proteins, application of electric fields allowed incorporation of higher amounts of $\mathrm{Fe}^{2+}$ within the protein matrix without compromising the hydrogel microstructure stability. Whey protein gels were stable against physical disruption when produced at a MEF of $3 \mathrm{~V} \cdot \mathrm{cm}^{-1}$ and combined with a cold gelation using $33 \mathrm{mmol} \cdot \mathrm{L}^{-1}$ of $\mathrm{Fe}^{2+}$. Ohmic heating may be widely used as a technological tool for the manufacture of gelling systems that can act as food thickeners, or also be used for transport/delivery of bioactive or functional biomolecules (such as iron) - thus offering the opportunity to increase the nutritional and dietary value of innovative functional foods.

\section{Acknowledgements}

This study was supported by the Portuguese Foundation for Science and Technology (FCT) under the scope of the strategic funding of UID/ BIO/04469/2013 unit and COMPETE 2020 (POCI-01-0145-FEDER006684) and BioTecNorte operation (NORTE-01-0145-FEDER-000004) funded by European Regional Development Fund under the scope of Norte2020 - Programa Operacional Regional do Norte. Rui M. Rodrigues, Oscar L. Ramos and Ricardo N. Pereira and, gratefully acknowledge to FCT their financial grants with references SFRH/BD/ 110723/2015, SFRH/BPD/80766/2011 and SFRH/BPD/81887/2011, respectively.

\section{References}

Akkermans, C., Van der Goot, A. J., Venema, P., Van der Linden, E., \& Boom, R. M. (2008). Properties of protein fibrils in whey protein isolate solutions: Microstructure, flow behaviour and gelation. International Dairy Journal, 18(10 - 11), 1034-1042.

Ako, K., Nicolai, T., \& Durand, D. (2010). Salt-induced gelation of globular protein ag gregates: Structure and kinetics. Biomacromolecules, 11(4), 864-871.

Alexander, D. L. J., Tropsha, A., \& Winkler, D. A. (2015). Beware of R(2): Simple, unambiguous assessment of the prediction accuracy of QSAR and QSPR models. Journal of Chemical Information and Modeling, 55(7), 1316-1322.

Alibabić, V., Šertović, E., Mujić, I., Živković, J., Blažić, M., \& Zavadlav, S. (2016). The level of nutrition knowledge and dietary iron intake of Bosnian women. Procedia Social and Behavioral Sciences, 217, 1071-1075.

Anema, S. G. (2008). Effect of milk solids concentration on the gels formed by the acidification of heated pH-adjusted skim milk. Food Chemistry, 108(1), 110-118.

Anema, S. G., \& Li, Y. M. (2003). Association of denatured whey proteins with casein micelles in heated reconstituted skim milk and its effect on casein micelle size. Journal of Dairy Research, 70(1), 73-83.

Beck, K. L. (2015). Anemia: Prevention and dietary strategies. In B. Caballero, P. Finglas, \& F. Toldra (Eds.), Encyclopedia of Food and Health (pp. 164-168). Oxford, U.K: Academic Press.

Bourbon, A. I., Pinheiro, A. C., Carneiro-da-Cunha, M. G., Pereira, R. N., Cerqueira, M. A., \& Vicente, A. A. (2015). Development and characterization of lactoferrin-GMP nanohydrogels: Evaluation of $\mathrm{pH}$, ionic strength and temperature effect. Food Hydrocolloids, 48(0), 292-300. 
Bryant, C. M., \& McClements, D. J. (1998). Molecular basis of protein functionality with special consideration of cold-set gels derived from heat-denatured whey. Trends in Food Science \& Technology, 9(4), 143-151.

Bryant, C. M., \& McClements, D. J. (2000). Influence of $\mathrm{NaCl}$ and $\mathrm{CaCl} 2$ on cold-set gelation of heat-denatured whey protein. Journal of Food Science, 65(5), 801-804.

Chen, H., Chang, X., Du, D., Li, J., Xu, H., \& Yang, X. (2006). Microemulsion-based hydrogel formulation of ibuprofen for topical delivery. International Journal of Pharmaceutics, 315(1-2), 52-58.

Derringer, G., \& Suich, R. (1980). Simultaneous-optimization of several response variables. Journal of Quality Technology, 12(4), 214-219.

Dissanayake, M., Ramchandran, L., Piyadasa, C., \& Vasiljevic, T. (2013). Influence of heat and $\mathrm{pH}$ on structure and conformation of whey proteins. International Dairy Journal, 28(2), 56-61.

Ewoldt, R. H., Johnston, M. T., \& Caretta, L. M. (2015). Experimental challenges of shear rheology: How to avoid bad data. In S. E. Spagnolie (Ed.), Complex fluids in biological systems: Experiment, theory, and computation (pp. 207-241). New York, NY: Springer New York.

Foegeding, E. A., \& Davis, J. P. (2011). Food protein functionality: A comprehensive approach. Food Hydrocolloids, 25(8), 1853-1864.

Gimel, J. C., Durand, D., \& Nicolai, T. (1994). Structure and distribution of aggregates formed after heat-induced denaturation of globular proteins. Macromolecules, 27(2), 583-589.

Hudson, H. M., Daubert, C. R., \& Foegeding, E. A. (2000). Rheological and physical properties of Derivitized whey protein isolate powders. Journal of Agricultural and Food Chemistry, 48(8), 3112-3119.

Ikeda, S., \& Morris, V. J. (2002). Fine-stranded and particulate aggregates of heat-denatured whey proteins visualized by atomic force microscopy. Biomacromolecules, 3(2), 382-389.

Kavanagh, G. M., Clark, A. H., \& Ross-Murphy, S. B. (2000). Heat-induced gelation of globular proteins: Part 3. Molecular studies on low pH $\beta$-lactoglobulin gels. International Journal of Biological Macromolecules, 28(1), 41-50.

Lei, L., Zhi, H., Xiujin, Z., Takasuke, I., \& Zaigui, L. (2007). Effects of different heating methods on the production of protein-lipid film. Journal of Food Engineering, 82(3), 292-297.

Li, J. S., Ma, C. Q., Ma, Y. H., Li, Y., Zhou, W., \& Xu, P. (2007). Medium optimization by combination of response surface methodology and desirability function: An application in glutamine production. Applied Microbiology and Biotechnology, 74(3), 563-571.

Mang, D. Y., Abdou, A. B., Njintang, N. Y., Djiogue, E. J. M., Loura, B. B., \& Mbofung, M. C. (2015). Application of desirability-function and RSM to optimize antioxidant properties of mucuna milk. Journal of Food Measurement and Characterization, 9(4), 495-507.

Marangoni, A. G., Barbut, S., McGauley, S. E., Marcone, M., \& Narine, S. S. (2000). On the structure of particulate gels-The case of salt-induced cold gelation of heat-denatured whey protein isolate. Food Hydrocolloids, 14(1), 61-74.

Martin, A. H., \& de Jong, G. A. (2012a). Enhancing the in vitro Fe(2 +) bio-accessibility using ascorbate and cold-set whey protein gel particles. Dairy Science and Technology, 92(2), 133-149.

Martin, A. H., \& Jong, G. A. H. (2012). Impact of protein pre-treatment conditions on the iron encapsulation efficiency of whey protein cold-set gel particles. European Food Research and Technology, 234(6), 995-1003.

Nakano, T., Goto, T., Nakaji, T., \& Aoki, T. (2007). Bioavailability of iron-fortified whey protein concentrate in iron-deficient rats. Asian-Australasian Journal of Animal Sciences, 20(7), 1120-1126.

Nicolai, T., Britten, M., \& Schmitt, C. (2011). $\beta$-Lactoglobulin and WPI aggregates: Formation, structure and applications. Food Hydrocolloids, 25(8), 1945-1962.

Nicorescu, I., Loisel, C., Vial, C., Riaublanc, A., Djelveh, G., Cuvelier, G., \& Legrand, J.
(2008). Combined effect of dynamic heat treatment and ionic strength on denaturation and aggregation of whey proteins - Part I. Food Research International, 41(7), 707-713.

Nobbmann, U., \& Morfesis, A. (2009). Light scattering and nanoparticles. Materials Today, 12(5), 52-54.

Oski, F. A. (1993). Iron deficiency in infancy and childhood. New England Journal of Medicine, 329(3), 190-193.

Patel, S. (2015). Functional food relevance of whey protein: A review of recent findings and scopes ahead. Journal of Functional Foods, 19, 308-319 (Part A).

Pereira, R. N., Rodrigues, R. M., Ramos, Ó. L., Xavier Malcata, F., Teixeira, J. A., \& Vicente, A. A. (2015). Production of whey protein-based aggregates under Ohmic heating. Food and Bioprocess Technology, 1-12.

Pereira, R. N., Souza, B. W., Cerqueira, M. A., Teixeira, J. A., \& Vicente, A. A. (2010) Effects of electric fields on protein unfolding and aggregation: Influence on edible films formation. Biomacromolecules, 11(11), 2912-2918.

Pereira, R. N., Teixeira, J. A., \& Vicente, A. A. (2011). Exploring the denaturation of whey proteins upon application of moderate electric fields: A kinetic and thermodynamic study. Journal of Agricultural and Food Chemistry, 59(21), 11589-11597.

Powers, J. M., \& Buchanan, G. R. (2014). Diagnosis and Management of Iron Deficiency. Anemia, Hematology/Oncology Clinics of North America, 28(4), 729-745.

Pullara, F., Guerrero-Santoro, J., Calero, M., Zhang, Q. M., Peng, Y., Spahr, H., ... Levine, A. S. (2013). A general path for large-scale solubilization of cellular proteins: From membrane receptors to multiprotein complexes. Protein Expression and Purification, $87(2), 111-119$.

Ramos, O. L., Pereira, R. N., Rodrigues, R., Teixeira, J. A., Vicente, A. A., \& Xavier Malcata, F. (2014). Physical effects upon whey protein aggregation for nano-coating production. Food Research International, 66, 344-355.

Remondetto, G. E., Beyssac, E., \& Subirade, M. (2004). Iron availability from whey protein hydrogels: An in vitro study. Journal of Agricultural and Food Chemistry, 52(26), 8137-8143.

Remondetto, G. E., Paquin, P., \& Subirade, M. (2002). Cold gelation of b-lactoglobulin in the presence of iron. Journal of Food Science, 67(2), 586-595.

Remondetto, G. E., \& Subirade, M. (2003). Molecular mechanisms of Fe2 + - induced beta-lactoglobulin cold gelation. Biopolymers, 69(4), 461-469.

Resch, J. J., Daubert, C. R., \& Foegeding, E. A. (2005). Beta-lactoglobulin gelation and modification: Effect of selected acidulants and heating conditions. Journal of Food Science, 70(1), C79-C86.

Rodrigues, R. M., Martins, A. J., Ramos, O. L., Malcata, F. X., Teixeira, J. A., Vicente, A. A., \& Pereira, R. N. (2015). Influence of moderate electric fields on gelation of whey protein isolate. Food Hydrocolloids, 43, 329-339.

Roefs, S. P. F. M., \& De Kruif, K. G. (1994). A model for the denaturation and aggregation of B-Lactoglobulin. European Journal of Biochemistry, 226(3), 883-889.

Ruben, M.-P., \& Sundaram, G. (2009). Gelation and thickening with globular proteins at low temperatures. Novel Food Processing (pp. 147-186). CRC Press.

Sağlam, D., Venema, P., de Vries, R., Shi, J., \& van der Linden, E. (2013). Concentrated whey protein particle dispersions: Heat stability and rheological properties. Food Hydrocolloids, 30(1), 100-109.

Tecante, A. (2009). Viscoelasticity. In G. V. Barbosa-Cánovas (Vol. Ed.), Food Engineering. Vol. II. Oxford, United Kingdom: EOLSS/UNESCO.

Totosaus, A., Montejano, J. G., Salazar, J. A., \& Guerrero, I. (2002). A review of physical and chemical protein-gel induction. International Journal of Food Science and Technology, 37(6), 589-601.

World Health Organization (2001). Iron deficiency anaemia. Assessment, prevention, and control. A guide for programme managers. Geneva http://www.who.int/iris/handle/ $10665 / 66914$.

Yada, R. Y., Jackman, R. L., \& Smith, J. L. (1994). Protein structure - function relationship in foods. New York: Springer Science + Business Media. 